\title{
Effects of additives and their levels of inclusion on nutritive value of silage made
} from elephant grass (Pennisetum purpureum)

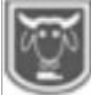

*Baba, M., Nasir, A., Kabiru, A., Erakpotobor, M. and Umar, G. A. Department of Animal Science, Bayero University Kano Abstract

*Corresponding author: babamuhammad01@yahoo.com; 09091532475.

The experiment was conducted to determine the effects of three additives (molasses, cracked corn and corn-soybean) and inclusion levels (0, 2.5, 5, 7.5 and $10 \%)$ on nutritive value of elephant grass (Pennistum purpureum) silage. The experimental design was a $3 \times 5$ factorial in a completely randomized design with each treatment replicated three times. Samples were obtained from Pasture Museum. Elephant grass stands at late vegetative stage were randomly selected and harvested at $7 \mathrm{~cm}$ stubble height. Grass was chopped into 2-3 cm length. Five hundred gram of the sample was weighed in each case; additives were added separately at the designated inclusion levels and mixed thoroughly. Materials were then tightly packed into laboratory silos compressed and sealed tightly and left for a fermentation period of 21 days. The results indicated crude protein (CP) was significantly greater $(10.92 \%)$ in silage treated with corn-soybean additive compared with other additives. Crude fiber (CF) was observed to be lower in molasses treated elephant grass silage (27.74\%). Acid detergent fiber $(A D F)$ and neutral detergent fiber (NDF) were both lower in molasses treated silage (24.76 and $43.26 \%$ respectively). The CP was observed to increase with increased inclusion level of the additive while CF decreased. Values for digestible dry matter (DDM), dry matter intake (DMI)as a percentage of body weight and relative feed value $(R F V)$ were greater $(P<0.05)$ in molasses treated silage compared to corn and corn-soybean. The DDM, DMI and RFV values were higher $(P<0.05)$ at 7.5 and $10 \%$ inclusion levels. Significant interactions were observed between additives and inclusion levels in most parameters measured. It was concluded that molasses additive could be used in elephant grass silage during ensiling at 7.5-10\% levels of inclusion.

Keywords: Additives, Grass, inclusion levels, Silage, Nutritive value

\section{Introduction}

Livestock production in Nigeria as in many regions of the world is beset with enormous problem chiefly among, which is lack of feed adequacy throughout the year in terms of quantity and quality. The consequences on animal production are decrease in body weight, meat and milk production as well as reduced reproductive ability among others. One of the ways to mitigate the problem of feed adequacy is through conservation of excess forage produced during the rainy season as hay or silage to be fed during the dry season. Hay is formed by drying under the sun or through artificial driers to a safe moisture content of about $15 \%$ whereas silage is formed by controlled fermentation which entails decreasing the $\mathrm{pH}$ within minimum fermentation period. In silage, lack of oxygen and the accumulation of lactic acid inhibit its microbial metabolism and preserve nutrients (Ranjit and Kung, 2000).

Grasses and legumes could be conserved as silage, however, because of the high moisture content of legumes, grasses are favored for silage making although combination of grass and legumes can also make good silage. McDonald et al. (1991) reported that ensiling forage material with high moisture content can adversely affect fermentation quality of silage. One of the grasses that have strong potential for silage making is Pennisetum purpureum known as elephant grass. Elephant grass is very important forage in the tropics due to its high productivity. In high potential areas annual dry matter yield of elephant grass 


\section{Nutritive value of silage made from elephant grass (Pennisetum purpureum)}

has been reported to range from 30 to 50 tons Dm/ha (Mtengeti et al., 2001), Much of the yield is usually realized during the rainy season. Elephant grass is mainly used in cut and carry system (Zero grazing) and fed in stalls or made into silage or hay. It can be grazed provided it can be kept at the lush vegetative stage. Livestock tend to feed only the younger leaves (FAO, 2015). Elephant grass as the name implies is an important source of forage for elephants in Africa (CooK et al., 2005). One of the factors that may interfere with fermentation quality of silage made from tropical grasses and elephant grass in particular is the low soluble carbohydrate content of the grasses. Iqbal et al. (2005) reported that mott grass has low concentration of fermentable carbohydrate and suggested that addition of additives can improve silage quality. In the same connection, using molasses or corn as addttive can increase the amount of fermentation end products due to fermentation of the available sugar (Yakota et al., 1992). The objective of the experiment therefore was to determine the effects of addition of cracked corn, combination of corn and soybean and molasses at graded levels on the quality of elephant grass silage

\section{Materials and methods}

The experiment was conducted at the Laboratory of Animal Science Department of Bayero University Kano, Nigeria. Kano state is located between latitude $11^{\circ} 58^{\prime} \mathrm{N}$ and longitude $08^{\circ} 28.79^{\prime} \mathrm{E}$ at an altitude of $460 \mathrm{~m}$ above sea level in Sudan savanna zone of Nigeria (KNARDA, 2001). The climate of the study area is characterized by a wet season which normally begins in May and ends in September while the dry season lasts from October to April. The mean annual rainfall vary from $600-1000 \mathrm{~mm}$ and temperature between $30-33^{\circ} \mathrm{C}$

\section{Experimental material}

The material used for silage making was obtained from stands of elephant grass in the pasture museum of the Livestock Teaching and Research Farm of the Department of Animal Science, with the grass at the late vegetative stage. The grass stands had an average height of $152 \mathrm{~cm}$ with 12 mean number of leaves per stand.

\section{Treatment and experimental design}

The treatments were three additives (cracked corn, mixed corn-soybean and molasses) and their levels of inclusion (0, 2.5, 5, 7.5 and 10\%). The experimental design was a $3 \times 5$ factorial in a completely randomized design

\section{Silage preparation}

Stands of elephant grass were harvested at 7 $\mathrm{cm}$ stubble height and chopped to about 2-3 $\mathrm{cm}$ length, Five hundred gram $(500 \mathrm{gm})$ of the sample was mixed with each of the additives at graded levels $(0,2.5$. 5, 7.5 and $10 \mathrm{w} / \mathrm{w})$. The mixture was tucked into laboratory silos, compressed to remove air pockets with a view to creating an anaerobic condition. The silos were sealed tightly with the aid of lids after grease was applied around their mouths. The materials in the silos were then allowed a fermentation period of 21 days. Following 21 days fermentation period, the resultant silage was scored for colour and aroma on a scale of 1-4 by 3 independent scorers.

Table: Description of colour and aroma scores used in assessing elephant grass (

Pennisetum purpureum) silage

\begin{tabular}{lll}
\hline Scale & Colour & Aroma \\
\hline 1 & Dark/Deep brown & Putrid or rancid \\
2 & Light brown & Pleasant \\
3 & Pale yellow & Sweet \\
4 & Yellowish green & Very Sweet \\
\hline Source: Kallah et al (1997) & &
\end{tabular}




\section{Baba, Nasir, Kabiru, Erakpotobor and Umar}

Thereafter, temperature was measured using mercury in glass thermometer; $\mathrm{pH}$ was also determined using digital $\mathrm{pH}$ meter. Subsample of the silages was taken and fresh weights measured. The samples were oven dried at $60^{\circ} \mathrm{C}$ for 48 hours. The oven dried samples were ground using hammer mill to pass through $2 \mathrm{~mm}$ sieve and used for chemical analysis

\section{Chemical analysis}

The analysis of crude protein was carried out using Kjeldhal method while percentage nitrogen was determined and multiplied by 6.25 . Other proximate constituents were determined according to AOAC (1995). Fiber fractions (ADF and NDF) were determined according to Van soest et al. (1991). Mineral contents (Ca, $\mathrm{Mg}, \mathrm{P}$ and $\mathrm{K}$ ) were determined by Atomic Absorption Spectrophotometer as described by AOAC (1999) and Flame Photometery. Other nutritive value parameters such as DMI, DDM and RFV were calculated as follows

$\mathrm{DMI}=(120 \div \mathrm{NDF} \%$ dry matter basis $)$

$\mathrm{DDM}=88.9-(0.779 \times \mathrm{ADF} \%$ dry matter basis)

$\mathrm{RFV}=(\mathrm{DDM} \% \times \mathrm{DMI} \% \times 0.775)$

(Horrocks and Vallentine, 1999)

\section{Data analysis}

The data collected were subjected to analysis of variance (Anova) Using SAS (2009) version 9.2. Differences among means were separated by Tukeys.

\section{Results}

Results of colour, aroma, temperature and $\mathrm{pH}$ characteristics of elephant grass silage treated with graded levels of corn, cornsoybean and molasses additives are shown in Table 2. The results revealed that irrespective of the type of additive used, the colour of all silages was yellowish green with sweet aroma. The $\mathrm{pH}$ and temperature values ranged from 3.7-4.8 and $22-23.7^{\circ} \mathrm{C}$, respectively. This suggests that satisfactory silage had been produced.

Table 2: Colour, aroma, temperature and $\mathrm{pH}$ characteristics of elephant grass silage treated with graded levels of corn, corn-soybean and molasses additives

\begin{tabular}{|c|c|c|c|c|c|c|c|c|c|c|c|c|}
\hline & Corn & Treatments & & & $\begin{array}{l}\text { Corn } \\
\text { and } \\
\text { Soybean }\end{array}$ & & & & Molasses & & & \\
\hline $\begin{array}{l}\text { Graded } \\
\text { levels } \\
\%\end{array}$ & $\mathrm{C}$ & $\mathrm{A}$ & $\mathrm{T}^{\circ} \mathrm{C}$ & $\mathrm{pH}$ & $\mathrm{C}$ & A & $\mathrm{T}^{\circ} \mathrm{C}$ & $\mathrm{pH}$ & $\mathrm{C}$ & A & $\mathrm{T}^{\circ} \mathrm{C}$ & $\mathrm{pH}$ \\
\hline 0 & YG & S & 22 & 4.4 & YG & $S$ & 23 & 4.5 & YG & S & 22 & 4.6 \\
\hline 2.5 & YG & S & 22.4 & 4.8 & YG & S & 23 & 4.3 & YG & S & 22 & 4.4 \\
\hline 5 & YG & S & 23.1 & 4.2 & YG & S & 23.7 & 4 & YG & S & 22.8 & 4.0 \\
\hline 7.5 & YG & S & 22 & 4.6 & YG & S & 22.5 & 3.9 & YG & S & 22.8 & 3.8 \\
\hline 10 & YG & $S$ & 22.8 & 3.9 & $Y G$ & $S$ & 22.2 & 3.8 & $Y G$ & $S$ & 22.3 & 3.7 \\
\hline
\end{tabular}

Main and interaction effects of additives, levels of inclusion on proximate and fibre composition of elephant grass silage

Main and interaction effects of additives and concentration on proximate and fiber composition of elephant grass silage are shown in Table 3 . The proximate constituents of elephant grass silages treated with corn, corn-soybean and molasses were significantly affected by the type and levels of inclusion of the additives. Percentage dry matter (DM) was significantly $(\mathrm{P}<0.05)$ greater in molasses treated elephant grass silage (M, $96.29 \%)$ compared to corn-soybean (CS, $89.47 \%$ ) and corn $(\mathrm{C}, 88.62 \%)$ treated. The difference was in the order molasses $>$ cornsoybean>corn. In the case of level of 


\section{Nutritive value of silage made from elephant grass (Pennisetum purpureum)}

inclusion, DM percentage was significantly the highest $(\mathrm{P}<0.05)$ in the control $(92.23 \%)$ than all other levels of inclusion. Non-significant $(\mathrm{P}>0.05)$ difference was observed among $2.5,5$ and $7.5 \%$ levels of inclusion of additives. However, $10 \%$ had significantly lower DM than 2.5 and 7.5. Percentage ash (6.69 $\%)$, crude protein $(\mathrm{CP}, 10.92 \%)$ and Ether extract (EE, $3.65 \%)$ were significantly superior $(\mathrm{P}<0.05)$ in silage treated with corn-soybean additive compared to corn: ash (3.87), CP (8.39), EE (2.64) and molasses: ash $(3.71 \%), \mathrm{CP}(8.67 \%), \mathrm{EE}$ $(2.75 \%)$. The difference was in the order corn-soybean $>$ corn $>$ molasses for ash and corn-soybean $>$ molasses $>$ corn for crude protein and ether extract. Percentages of ash, $\mathrm{CP}$ and $\mathrm{EE}$ were significantly affected by levels of inclusion of additives. Percentages of the trio were significantly higher $(\mathrm{P}<0.05)$ at $10 \%$ level of inclusion compared to other levels. In the case of $\mathrm{CP}$ and $\mathrm{EE}$ the difference was in the order 10 $\%>7.5 \%>5 \%>2.5 \%>0 \%$. No definite trend was observed with respect to ash. This may connote addition of corn, cornsoybean and molasses at ensiling increased the content of the proximate constituents. Nitrogen free extract (NFE) was significantly $(\mathrm{P}<0.05)$ higher in silage treated with molasses (57.11\%) compared to corn treated $(54.93 \%)$ and con-soybean $(47.26 \%)$. The NFE was greater $(\mathrm{P}<0.05)$ in the control (0\%) compared to 7.5 and 10 $\%$ levels of inclusion. No significant difference was observed among 2.5, 5 and $7.5 \%$. However, 2.5 and $5 \%$ had significantly $(\mathrm{P}<0.05)$ greater NFE than 10 $\%)$.

Crude fiber (CF) acid detergent fiber (ADF) and neutral detergent fiber (NDF) were significantly $(\mathrm{P}<0.05)$ higher in cornsoybean and corn treated silages compared to molasses treated. The difference was in the order Corn-Soybean $>$ Corn $>$ Molasses for $\mathrm{CF}$ and ADF. No significant difference was observed between corn-soybean and corn treated silages in terms of $\mathrm{CF}$ and NDF. ADF contents of the three silages were significantly different $(\mathrm{P}<0.05)$ with corn-soybean treated silage having the highest ADF (31.64 \%) followed by corn treated (29.18) and molasses treated (24.76 $\%$ ). Crude fiber and ADF were significantly $(\mathrm{P}<0.05)$ highest in the control (silage without additives). The $\mathrm{CF}$ content declined with increase in level of inclusion of additives. Similar trend was observed in the case of $\mathrm{ADF}$ up to $7.5 \%$ level of inclusion. No definite trend was observed in NDF.

Table 3: Main effects of additives, levels of inclusion and interaction on proximate and fiber fractions $(\%)$ of elephant grass silage

\begin{tabular}{|c|c|c|c|c|c|c|c|c|}
\hline Additives & DM & $\mathrm{ASH}$ & $\mathrm{CP}$ & $\mathrm{CF}$ & EE & NFE & $\mathrm{ADF}$ & NDF \\
\hline Corn-Soybean & $89.47^{b}$ & $6.69^{a}$ & $10.92^{\mathrm{a}}$ & $31.48^{\mathrm{a}}$ & $3.65 a$ & $47.26^{\mathrm{c}}$ & $31.64^{\mathrm{a}}$ & $48.89^{a}$ \\
\hline Corn & $88.62^{\mathrm{c}}$ & $3.87^{\mathrm{b}}$ & $8.39^{c}$ & $30.69^{a}$ & $2.64 b$ & $54.93^{b}$ & $29.18^{\mathrm{b}}$ & $48.94^{\mathrm{a}}$ \\
\hline Molasses & $96.29^{\mathrm{a}}$ & $3.71^{b}$ & $8.67^{b}$ & $27.74^{\mathrm{b}}$ & $2.75 b$ & $57.11^{\mathrm{a}}$ & $24.76^{\mathrm{c}}$ & $43.26^{\mathrm{b}}$ \\
\hline $\mathrm{P}$ value & 0.0001 & 0.0001 & 0.0001 & 0.0001 & 0.0001 & 0.0001 & 0.0001 & 0.0001 \\
\hline SEM & 0.063 & 0.184 & 0.017 & 0.170 & 0.023 & 0.160 & 0.328 & 0.246 \\
\hline \multicolumn{9}{|l|}{ Inclusion (\%) } \\
\hline 0 & $92.23^{\mathrm{a}}$ & $4.5^{\mathrm{ab}}$ & $8.68^{\mathrm{e}}$ & $31.37^{\mathrm{a}}$ & $1.76^{\mathrm{e}}$ & $54.57^{\mathrm{a}}$ & $31.69^{\mathrm{a}}$ & $47.20^{\mathrm{ab}}$ \\
\hline 2.5 & $91.51^{\mathrm{b}}$ & $4.0^{\mathrm{b}}$ & $9.08^{\mathrm{d}}$ & $31.12^{\mathrm{a}}$ & $2.47^{\mathrm{d}}$ & $53.34^{\mathrm{ab}}$ & $29.31^{\mathrm{ab}}$ & $48.94^{\mathrm{a}}$ \\
\hline 5 & $91.17^{\mathrm{bc}}$ & $4.34^{\mathrm{ab}}$ & $9.33^{c}$ & $29.53^{b c}$ & $3.31^{\mathrm{c}}$ & $53.48^{\mathrm{ab}}$ & $29.22^{\mathrm{ab}}$ & $46.65^{\mathrm{b}}$ \\
\hline 7.5 & $91.61^{\mathrm{b}}$ & $5.04^{\mathrm{ab}}$ & $9.59^{b}$ & $28.99^{c}$ & $3.55^{\mathrm{b}}$ & $52.79^{\mathrm{bc}}$ & $25.5^{0 \mathrm{c}}$ & $45.53^{\mathrm{b}}$ \\
\hline 10 & $90.77^{\mathrm{c}}$ & $5.91^{\mathrm{a}}$ & $9.97^{\mathrm{a}}$ & $28.87 \mathrm{c}$ & $3.94^{\mathrm{a}}$ & $51.35^{\mathrm{c}}$ & $26.92^{b c}$ & $46.89^{\mathrm{ab}}$ \\
\hline $\begin{array}{l}\mathrm{P} \text { value } \\
\text { interaction }\end{array}$ & 0.0001 & 0.024 & 0.0001 & 0.0001 & 0.0001 & 0.0001 & 0.0001 & 0.0036 \\
\hline Addt * IL & $* *$ & $*$ & $* *$ & $* *$ & $* *$ & $* *$ & $* *$ & $* *$ \\
\hline
\end{tabular}


Interaction between additives and their inclusion levels on dry matter of elephant grass silage (Figure 1) reveals that percentage $\mathrm{DM}$ was significantly $(\mathrm{P}<0.05)$ highest in molasses treated silage compared to corn-soy and corn treated at all levels of inclusion.

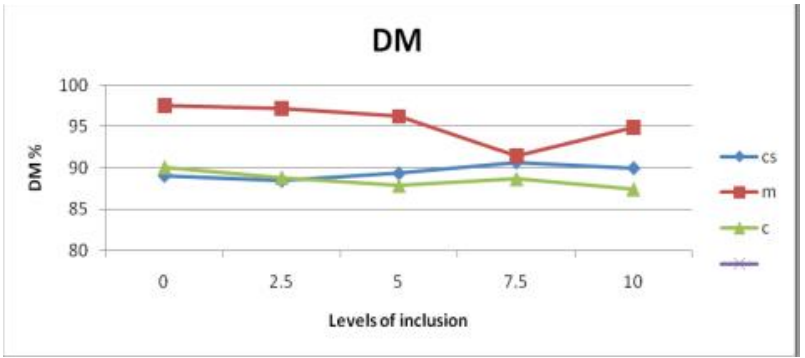

Figure I: Interaction effects of additives and inclusion levels on dry matter of elephant grass silage

Ash was significantly $(\mathrm{P}<0.05)$ higher when elephant grass was treated with cornsoybean mixture at all levels of inclusion except at $0 \%$ where no difference was observed among the silages treated with the different additives (Figure 2).
Comparatively molasses treated silage had greater $(\mathrm{P}<0.05)$ ash content than corn treated at 5, 7.5, and $10 \%$ inclusion levels. The highest Ash content was obtained in silage treated with $10 \%$ corn-soybean mixture.

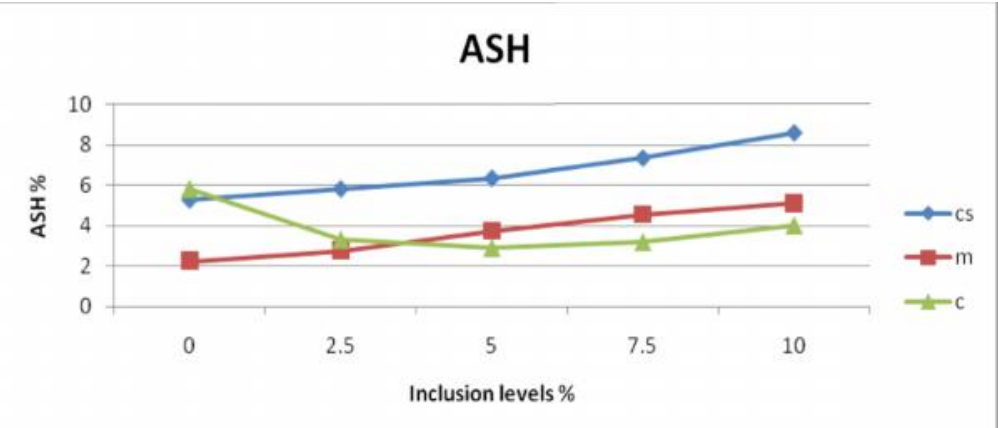

Figure 2: Interaction effects of additives and inclusion levels on Ash content of elephant grass silage

Crude protein was statistically $(\mathrm{P}<0.05)$ superior in silage treated with corn-soybean at all levels of inclusion compared to other silages, in the same connection, molasses treated silage had greater $(\mathrm{P}<0.05) \quad \mathrm{CP}$ values than corn treated except at $0 \%$ level of inclusion (Figure 3). The highest CP value was obtained in corn-soybean treated silage at $10 \%$ inclusion level.

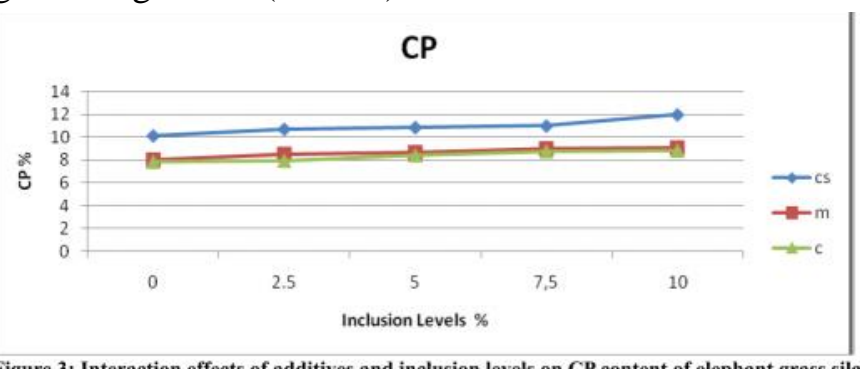

Figure 3: Interaction effects of additives and inclusion levels on CP content of elephant grass silage 


\section{Nutritive value of silage made from elephant grass (Pennisetum purpureum)}

ADF was significantly $(\mathrm{P}<0.05)$ lower in molasses treated silage compared to other silages except at $5 \%$ level of inclusion where no significant difference was observed between corn-soybean and molasses treated silages (Figure 4). Furthermore, all the three silages were not significantly different at $10 \%$ inclusion levels. The lowest ADF value was recorded in corn treated silage at $2.5 \%$.

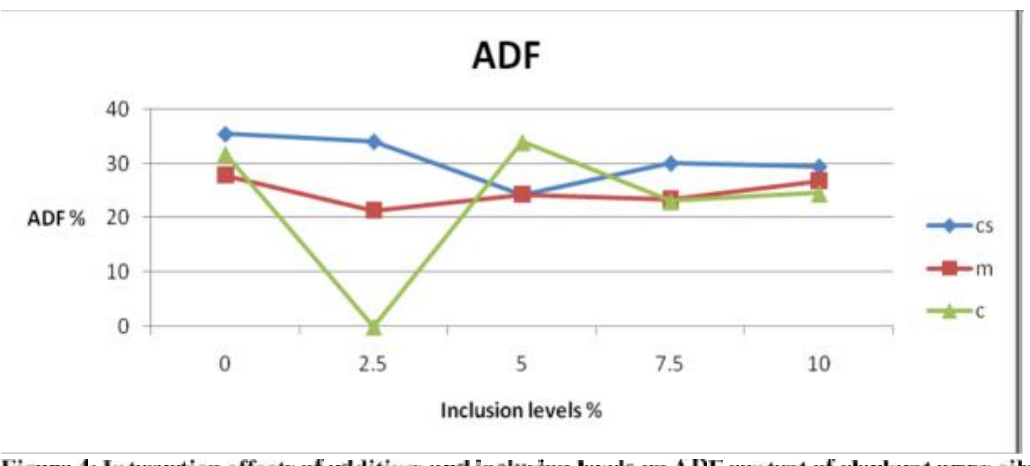

Figure 4: Interaction effects of additives and inclusion levels on ADF content of elephant grass silage

The NDF was similarly the lowest $(\mathrm{P}<0.05)$ in silage treated with molasses compared to other silages (Figure 5). There was no significant difference between cornsoybean and molasses treated silages at 0 and $2.5 \%$ inclusion levels, in the same connection, corn-soybean and corn treated silages were at par at $10 \%$. Lowest NDF value was observed in molasses treated silage at $0 \%$

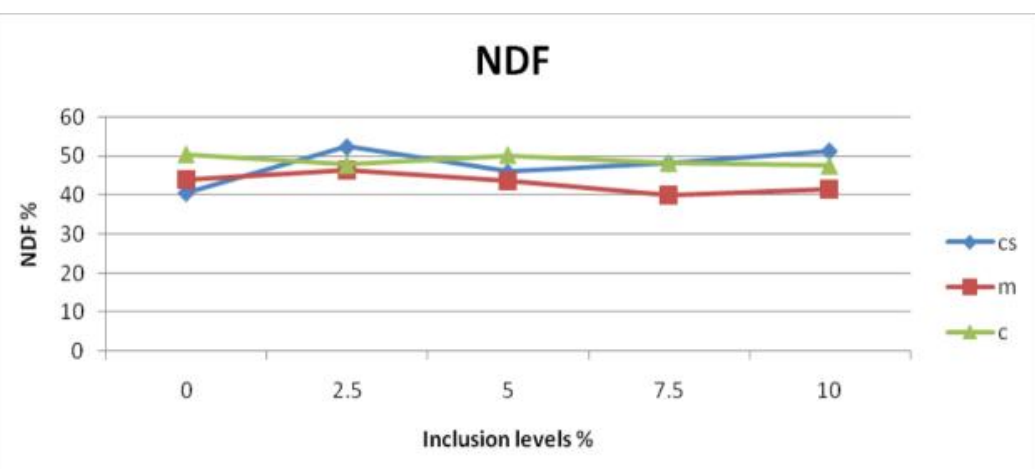

\section{silage \\ Main effects of additives levels of inclusion and interaction on Digestible dry matter, dry matter intake, relative feed value and mineral composition composition of elephant grass silage}

Figure 5; Interaction effects of additives and inclusion levels on NDF content of elephant urass

Main effects of additives, levels of inclusion and interaction on Digestible dry matter, dry matter intake, relative feed value and mineral composition of elephant grass silage are shown in Table 4. Digestible dry matter (DDM) dry matter intake as a percentage of body weight (DMI) and relative feed value were significantly different among the silages treated with the three additives, the values for DDM DMI and RFV were significantly the highest $(\mathrm{P}<0.05)$ in molasses treated silage compared to corn and corn soybean treated. In the case of DDM, the difference was in the order molasses $(69.61 \%)>$ corn $(66$. $\%)>$ corn-soybean $(64.25 \%)$. Similar trend was observed in the case of DMI although both corn and con-soybean treated silages were not significantly different ditto for 
RFV. DDM, DMI and RFV recorded higher values $(\mathrm{P}<0.05)$ at $7.5 \%$ level of inclusion compared to other levels. No significant difference was observed between $\mathrm{n} 7.5$ and $10 \%$. DMI was also significantly $(\mathrm{P}<0.05)$ greater at $7.5 \%$ level of inclusion $(2.66 \%)$ but at par with 0,5 and $10 \%$. Mineral composition of elephant grass treated with the three additives was significantly different. Corn-soybean treated silage had higher calcium $(\mathrm{Ca})$, magnesium) $\mathrm{Mg}$, potassium $(\mathrm{K})$ and phosphorus $(\mathrm{P})$ contents than corn and molasses treated. No difference was observed in $\mathrm{Ca}, \mathrm{Mg}$ and $\mathrm{P}$ values between silages treated with corn and molasses. Similarly, no significant difference was found in the $K$ values of corn-soybean and molasses treated silages. The minerals $\mathrm{Ca}, \mathrm{Mg}, \mathrm{K}$ and $\mathrm{P}$ had significantly higher values at $10 \%$ level of inclusion of additives. In all cases the mineral composition of the silage increased with increase level of inclusion of the additives. There was no significant difference between 7.5 and $10 \%$ in $\mathrm{Mg}$ and $\mathrm{K}$, similarly, $\mathrm{K}$ values were not significantly different at 2.5 and $5 \%$. In the case of $\mathrm{P}$ the non significant difference was observed between 5 and $7.5 \%$.

Table 4: Main effects of additives levels of inclusion and interaction on digestible dry matter, dry matter intake, relative feed value and mineral composition of elephant grass silage

\begin{tabular}{|c|c|c|c|c|c|c|c|}
\hline Additives & DDM & DMI & RFV & $\mathrm{Ca}$ & $\mathrm{Mg}$ & $\mathrm{K}$ & $\mathrm{P}$ \\
\hline Corn + Soybean & $64.25^{\mathrm{c}}$ & $2.46^{\mathrm{b}}$ & $122.33^{b}$ & $0.71^{\mathrm{a}}$ & $0.45^{\mathrm{a}}$ & $1.49^{\mathrm{a}}$ & $0.27^{\mathrm{a}}$ \\
\hline Corn & $66.16^{\mathrm{b}}$ & $2.45^{\mathrm{b}}$ & $126.02^{\mathrm{b}}$ & $0.50^{\mathrm{b}}$ & $0.32^{\mathrm{b}}$ & $1.26^{\mathrm{b}}$ & $0.23^{\mathrm{b}}$ \\
\hline Molasses & $69.61^{\mathrm{a}}$ & $2.78^{\mathrm{a}}$ & $150.05^{\mathrm{a}}$ & $0.49^{b}$ & $0.34^{\mathrm{b}}$ & $1.39^{\mathrm{a}}$ & $0.25^{\mathrm{b}}$ \\
\hline $\mathrm{P}$ value & 0.0001 & 0.0001 & 0.0001 & 0.0001 & 0.0001 & 0.0005 & 0.0001 \\
\hline SEM & 0.256 & 0.015 & 0.767 & 0.007 & 0.009 & 0.020 & 0.002 \\
\hline \multicolumn{8}{|l|}{ Inclusion (\%) } \\
\hline 0 & $64.21^{\mathrm{c}}$ & $2.55^{\mathrm{ab}}$ & $127.43^{\mathrm{c}}$ & $0.18^{\mathrm{e}}$ & $0.18^{\mathrm{c}}$ & $1.02^{\mathrm{c}}$ & $0.20^{\mathrm{d}}$ \\
\hline 2.5 & $66.07^{\mathrm{bc}}$ & $2.46^{\mathrm{b}}$ & $126.25^{\mathrm{c}}$ & $0.36^{\mathrm{d}}$ & $0.29^{b}$ & $1.25^{\mathrm{b}}$ & $0.23^{c}$ \\
\hline 5 & $66.14^{\mathrm{bc}}$ & $2.58^{\mathrm{ab}}$ & $132.79^{b c}$ & $0.65^{\mathrm{c}}$ & $0.33^{\mathrm{c}}$ & $1.39^{\mathrm{b}}$ & $0.26^{\mathrm{b}}$ \\
\hline 7.5 & $69.04^{\mathrm{a}}$ & $2.66^{\mathrm{a}}$ & $142.11^{\mathrm{a}}$ & $0.73^{b}$ & $0.49^{a}$ & $1.64^{\mathrm{a}}$ & $0.27^{\mathrm{b}}$ \\
\hline 10 & $67.93^{\mathrm{ab}}$ & $2.58^{\mathrm{ab}}$ & $138.09^{\mathrm{ab}}$ & $0.92^{\mathrm{a}}$ & $0.56^{\mathrm{a}}$ & $1.61^{\mathrm{a}}$ & $0.29^{a}$ \\
\hline$P$ value & 0.0001 & 0.0047 & 0.0001 & 0.0001 & 0.0001 & 0.0001 & 0.0001 \\
\hline \multicolumn{8}{|l|}{ Interaction } \\
\hline Addt $*$ IL & $* *$ & $* *$ & ** & $*$ & ns & $* *$ & ns \\
\hline
\end{tabular}
significant

Interaction between additives and their levels of inclusion on digestible dry matter depicts molasses treated silage as having significantly $(\mathrm{P}<0.05)$ higher DDM at $2.5 \%$ compared to other silages (Figure, 6). Both molasses and corn treated silages were at par at 0 and $7.5 \%$. Similarly, no significant difference was observed among the three silages at $10 \%$. In the same connection, the DDM in corn-soy and molasses treated silages were not significantly different at 5 $\%$. The highest value for DDM was obtained in molasses treated silage at $2.5 \%$. Dry matter intake as a percentage of body weight was consistently the highest in molasses treated silage compared to other silages irrespective of levels of inclusion. Molasses treated silage had significantly $(\mathrm{P}<0.05)$ greater DMI at 2.5, 7.5 and $10 \%$. There was no significant difference between con-soy and molasses at 0 and 5\% levels of inclusion, however, both cornsoybean and molasses treated silages had significantly higher DMI at the stated levels of inclusion than corn treated. In the same vein corn-soybean and corn treated silages were statistically similar at 7.5 and $10 \%$ levels of inclusion. 


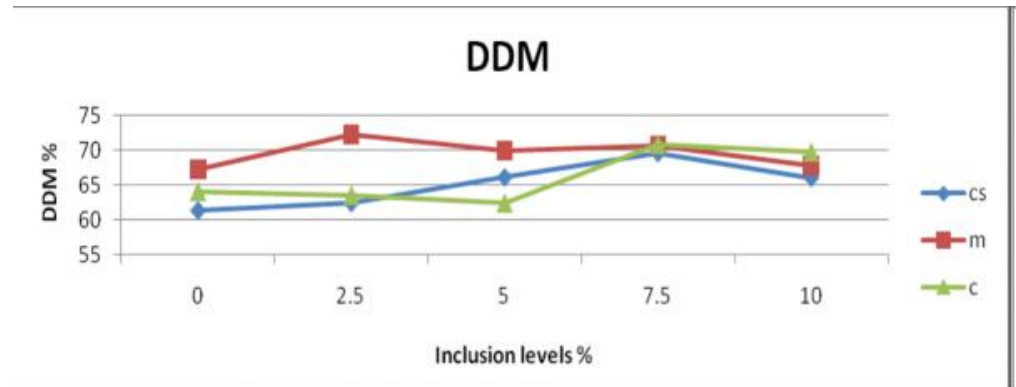

Figure 6: Interaction effects of additives and inclusion levels on DDM of elephant grass silage

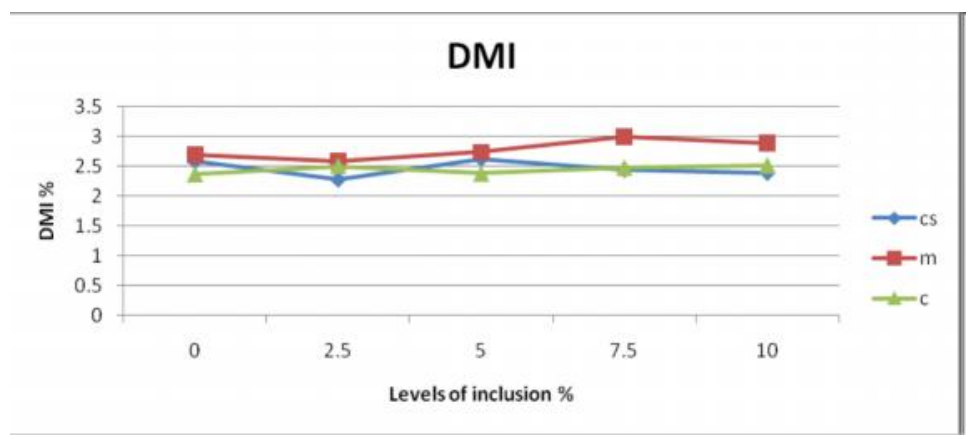

Figure 7: Interaction effects of additives and inclusion levels on DDM of elephant grass silage

Molasses treated silages had consistently higher relative feed value at all levels of inclusion. Significant difference was observed at $0,2.5,7.5$ and $10 \%$ inclusion levels. There was no significant difference between the RFV values of molasses treated and corn soybean treated silages at $5 \%$. Corn-soybean and corn treated silages had statistically similar RFV values at 0,5 and $7.5 \%$. However, RFV values were higher in corn treated silage at 2.5 and $10 \%$ than corn-soybean treated.

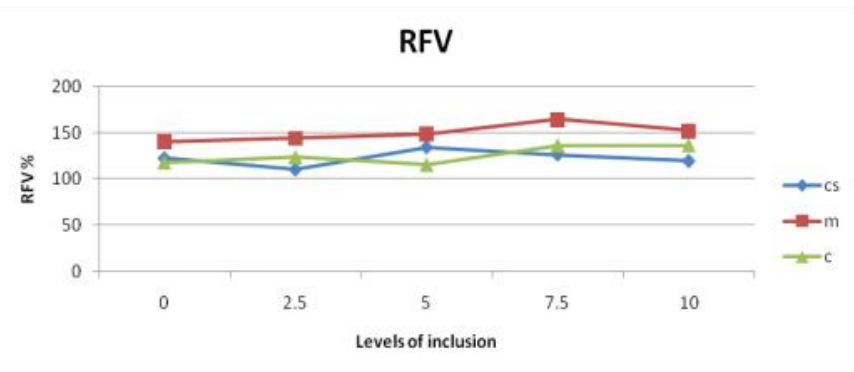

Figure 8: Interaction effects of additives and inclusion levels on RFV of elephant grass silage

\section{Discussion}

The quality of any silage depends on the efficiency of fermentation during ensiling. The whole idea of using additive during ensiling is to enhance fermentation through reduction in $\mathrm{pH}$ and increased production of lactic acid. Qamar (2009) reported that fermentation process was highly influenced by the availability of fermentable carbohydrate adding that additives decreased $\mathrm{pH}$ and increased lactic acid.

Main and interaction effects of additives and their concentration on proximate and fiber composition of elephant grass silage The results of the study (Table, 3 ) indicate dry matter percentage in molasses treated silage compared to corn-soybean and corn silages irrespective of the levels of 


\section{Baba, Nasir, Kabiru, Erakpotobor and Umar}

inclusion. This is supported by the work of Qamar (2009) who reported that molasses additive gave higher DM than corn in mott grass silage. He attributed the higher DM recovery with molasses to addition of water soluble carbohydrate that improved fermentation characteristics. In the same connection, Sharp et al. (1994) opined that increased DM recovery could have been due to homolactic fermentation which decreased fermentation loss. Comparatively the DM values for the control (0\% additive) were greater than those for additive treated silages. This agrees with the result of Kamarloiy and Teimouri (2008) and Kung et al. (1993) who observed lower DM in silages treated with additives compared to the control.

The higher Ash content in corn-soybean compared to other additives may be due to the higher mineral content in the companion soybean, moreover Ash is an indication of the mineral content of feed. The soybean in the corn-soybean additive could have added to aggregate amount of Ash in the form of minerals $(\mathrm{Ca}, \mathrm{Mg}, \mathrm{P}$ and $\mathrm{K})$. Furthermore, legumes generally have higher cation exchange capacity compared to grasses, that is, ability to absorb positively charged ions such as $\mathrm{Ca}^{2+}, \mathrm{Mg}^{2+}$ and $\mathrm{K}^{+}$

The higher $\mathrm{CP}$ and $\mathrm{EE}$ in corn-soybean compared to other additives could also be explained in the context of higher CP and oil in soybean which may have increased the overall CP and EE contents of the silage. This can further be explained by the upward trend observed in the values of these nutrients with increased addition of the additive (Corn-soybean).

The higher NFE recorded in molasses treated silage compared to other silages could have been due to the lowering of the fiber content (CF, NDF and ADF) of the silage by the additives and the fact that molasses proved superior in the lowering process. Another possible reason might be due to improved fermentation process made possible by the availability of water soluble carbohydrate (Molasses) as reported by Bolsen et al. (1996). Futhermore, the lower fiber observed in molasses treated silage compared to others can be attributed to greater hydrolysis of hemicelluloses in the molasses treated silage. Although the $\mathrm{pH}$ values of the three silages were comparable, however, there was bound to be higher rate of hydrolysis in the molasses treated silage by virtue of molasses being water soluble carbohydrate that can easily acidify the environment through $\mathrm{pH}$ reduction. Kamarloiy and Teimouri (2008) attributed an observed reduction in fiber content of silage to partial hydrolysis of hemicelluloses.

Main and interaction effects of additives and inclusion levels on DMI, DDM RFV and mineral composition of elephant grass silage

Molasses treated silage had higher values for DMI, DDM and RFV compared to other silages. This could be explained in the context that molasses treated silage had lower values for fiber (CF, $\mathrm{ADF}$ and $\mathrm{NDF}$ ). Both ADF and NDF are indices of measuring digestibility and feed intake in animals respectively. ADF is negatively related to digestibility while NDF to intake. Muck and Kung (1997) reported greater DMI for steers consuming inoculated silage than non inoculated. In the same vein, the digestibility of NDF was increased in steers fed inoculated corn silage compared to the control. Although inoculation was not part of the focus of this study, the overall aim of using additives or inoculants in silage making is to enhance fermentation through $\mathrm{pH}$ reduction and production of lactic acid, hence, additives and inoculum perform the same role. The observed higher value for minerals $(\mathrm{Ca}, \mathrm{Mg}, \mathrm{P}$ and $\mathrm{K})$ in the cornsoybean silage was expected. This could have been due to higher mineral content in soybean as explained earlier. The combined 
effects of minerals in corn and soybean are likely to raise the amount of minerals in the resultant silage.

Interaction effects of additives and their inclusion levels also affirmed the results of the main effects. It would appear that higher levels of inclusion gave better results in most of the parameters considered.

\section{Conclusion}

The study indicted higher values in DM, DDM, DMI and RFV for molasses treated silages in addition to lower values in fiber (CF, ADF and NDF) compared to corn and corn-soy additives. This is suggestive of good quality silage. By and large 7.5-10\% levels of inclusion of the additives gave better results. It can thus be recommended that molasses should be used in silage preparation of elephant grass at 7.5-10\% level of inclusion.

\section{Acknowledgement}

The authors gratefully acknowledge the contributions of the Centre for Dry Land Agriculture, Bayero University Kano in the area of funds for the research and Kabiru, A., Erakpotobor, M Umar, G. A all of whom partook in the field work

\section{References}

AOAC. 1995. Official Methods of Analysis $15^{\text {th }}$ edition. Association of Official Analytical chemists, Washington DC, USA.

AOAC. 1999. Association of official Analytical Chemists. Official Method of Analysis $18^{\text {th }}$ edition AOAC Inc, Arlingon, Virginia USA. 1094pp

Bolsen, K. K., Ashbell, G. and Weinberg, Z. 1996. Silage fermentation and silage additives. Asian-Aust Journal of Animal Science 9:483491.
Cook, B. Pengelly, B. C., Brown, S. D. and Schultze-Kraft, R. 2005. Utilization of elephant grass. Accessed on 10/01/18 from https://www. Feedipedia .org/node/1689.

FAO. 2015. Utilization of elephant grass. Accessed on 10/01/18 from https://www. Feedipedia .org/node/395

Horrocks, R. D. and Vallentine, J. F. 1993. Harvested Forages, Academic Press London, UK, pp:13

Iqbal, S. Bhatti, S. A. Mahrun, N. and Sarwar, 2005. Influence of varying levels of organic green culture and enzose on silage characteristics of Mott grass and its digestion kinetics in Nili Ravi buffalo bulls. International Journal of Agricultural Biology, 7(6)1011-1014

Kallah, M. S., Baba, M., Alawa, J. P., Muhammad, I. R. and Tanko, R. J. 1997. Ensiling quality of Columbus grass (Sorghum almum) grown in Northern Nigeria. Animal Feed Science and Technology, 68:153-163

Kamarloiy, M. and Teimouri, Y. 2008. Effect of microbial inoculants on the nutritive value of corn silage for beef cattle. Pakistan Journal of Biological Sciences, 11(8):11371141.

KNARDA. 2001. Kano Agricultural and Rural Development Authority. Meteorological station reports. Temperature Record book and Management Unit, 11:1-3.

Kung Jnr, L., Chen, H., Kreck, E. M. and Knutseen, K. 1993. Effect of microbial of corn silage on the inoculant nutritive value of lactating dairy cows. Journal of Dairy Science, 76:3763-3777 
Mc Donald, P., Henderson, A. R. and Heron, S. J. E 1991. The biochemistry of silage $2^{\text {nd }}$ edition, Chalcombe publication London Aberystwyth, U.K.

Mtengeti, E. J., Urio, N. A. and Mlay, G. I. 2001. Research note, intensive fodder gardens for improving fodder for small holder dairy production in Hai district, Tanzania. Tropical grasslands, 35:124-127

Muck, R. E. and Kung Jnr, L. 1997. Effects of silage additives on ensiling. Proceedings from the silage field feed bunk. North American Conference NRAES 99:187-199

Qamar, B. M. 2009. Effects of molasses and corn as silage additives on the characteristics of mott dwarf elephant grass at different fermentation periods. Pakistan Veterinary Journal, 29(1):19-23.
Ranjit, N. K. and Kung, L. 2000. The effect of lactobacillus butcheri, Lactobacillus plantarum or a chemical preservative on the fermentation and aerobic stability of corn silage. Journal of Dairy Science, 83:526-535

SAS. 2009. SAS Users Guide Version 9.2. SAS Institute Inc. Cary, NC, USA.

Sharp, R. P., Hooper, G. and Armstrong, D. G. 1994. The digestion of grass silages produced using inoculants of lactic acid bacteria. Grass Forage Science, 49:42-53.

Van Soest, P. J., Robertson, J. B. and Lewis, B. A. 1991. Methods of dietary fibre, neutral detergent fibre and non starch poly saccharides in relation to aniaml nutrition. Journal of Dairy Science, 74:35833597.

Yakota, H., Okajima, T. and Oshima, M. 1992. Effect of environmental temperature and addition of molasses on the quality of napier grass (Pennisetum purpureum) Asian-Aust Journal of Animal Science, 1(4):377-382.

Received: $10^{\text {th }}$ November, 2017

Accepted: $21^{\text {st }}$ February, 2018 